\title{
Physical education and language development
}

\author{
Werner Becker ${ }^{1}$, Romain Sahr ${ }^{2}$
}

1 University of Luxembourg, Faculty of Language and Literature, Humanities, Arts and Education, Route de Diekirch, L-7220 Walferdange, e-mail werner.becker@uni.lu

2 University of Luxembourg, Faculty of Language and Literature, Humanities, Arts and Education, Route de Diekirch, L-7220 Walferdange, e-mail romain.sahr@uni.lu

"Physical Education and Language Development" - a pilot project to network the promotion of physical education and language development of learning-disabled pupils in Luxemburg.

Abstract. Based on the hypothesis that in addition to increasing physical competence, intensified sports activity also promotes the development of general cognitive ability, the project's primary goal was to determine the current physical and language learning levels of the participating students and focus on their potential and on their acquisition of competences in the development of language skills accompanied by regular participation in sports activities. Due to the extraordinary interdependencies between physical education and language learning, focus on the mediation of key qualification, particularly in the social environment where the study took place, should be intensified.

Keywords: Physical education, language development.

\section{Formation and Planning of the pilot project}

\subsection{An assessment: Deficits in the spheres of language and motor skills of Luxem- burg pupils}

The results of the PISA study was a shock for the Luxemburg school system. It is precisely in the area of languages, where Luxemburg with its almost exemplary multilingualism, that the 15 year-olds with their third to last ranking in PISA (just before Mexico and Brazil) failed.

If the results of (the) PISA 2003 had been much better and some analyses and explanations helped to put the poor results into perspective, school policy did not, nonethe- 
less, stick its head in the sand, rather searched for improvement and reform. Thus in the field of languages, the action plan "Readjustment de l'enseignement des langues" (REL) comprised 66 measures for the years 2007 to 2009.

At approximately the same time, a study was published under the direction of Klaus Boes and initiated within the framework of the European Year of Education through Sports. This study of "health, motor fitness, and physical and athletic activity of children and youth in Luxembourg", revealed an important result: "The fact is that a large proportion of the children and youth do not meet the World Health Organization's minimum daily requirements for health-promoting and health-maintaining activity" (Boes, p. 251). Naturally, the schools are confronted with the task to improve this status "because virtually all children and youth are reached at school" (id. p. 253).

Such findings have generally lead educators and professionals to demand more teaching hours. In view of the many "construction sites" in a wide variety of fields, however, the schools do not have a solution in the form of increased, relevant school lessons at their disposal for the individual subjects.

\subsection{Physical education and language development as an interdisciplinary task}

The key words CLIL (Content and Language Integrative Learning) or "bilingual lesson" concept aim to promote the connection between language and content basically through interdisciplinary learning. With this in mind, several studies (compare Bergermann) have shown the possibility of combining, in particular, physical education with linguistic and communicative learning objectives. On this note, measure 53 of "Les Readjustment de l'enseignement des langues" earmarked a pilot project to link physical education and language-learning for school year 2007-2008.

In other linguistic contexts, it is mostly a question of whether or not, for example, physical education might offer the opportunity of foreign language acquisition and the integration thereof.

For Luxemburg, it is more so a question which language should be fostered through physical education, since as a rule Luxemburgish is the language of communication. However, in most of the other subjects, particularly in written communication, Luxemburgish plays no role; German and French are the languages of instruction. The complex language situation in an environment with many pupils whose first language of acquisition is not Luxemburgish, does not license an answer to this question from the outset.

\section{The Lycée du Nord as site for the pilot project}

The cooperation of several institutions (Department of Education, University of Luxemburg) resulted in the Lycée du Nord Wiltz (LNW) being selected for the implementation of the project. The site at Wiltz provided opportunity for the classic physical education class for experience education due to the proximity to the Esch / Sauer reservoir. Located there is the ministry of sports and its adjoining Lultzhausen Nautical Center 
that has access to the infrastructure for water sports, which in the canon of traditional sport subjects are less than adequately appreciated. Also the geographical/topographical infrastructural conditions in the environment surrounding the reservoir are suited to the practice of such sports as mountain biking or climbing.

Crucial was, however, the Wiltz teachers' interest in the project. Playing an important role was the physical education teacher, who also works for the LNW, but is also responsible for the activities at the Nautical Center.

\section{Learning-disabled pupils as project address data}

Similar to Germany, the Luxemburg school system is characterized by its tripartite structure, which begins with the seventh class. The LNW includes the high school track as well as the junior high school track (enseignement technique). Above and beyond, there is also the "enseignement préparatoire", which is comparable to the lower, general level secondary school.

PISA not only identified the poor result of Luxemburg pupils, rather additionally revealed a high interconnection between performance and the socio-economic conditions of the pupils. The study of health and motor and physical-athletic performance also observed grave deficits in the pupils' academic achievements for those pupils with worse academic performance (see Bös et al., 2006).

It was then ascertained that pupils with weaker academic achievement amass athletic and linguistic deficits. All the more, the project should attempt to find and identify ways to support these pupils at both levels.

The existence of an "enseignement préparatoire" in LNW provides opportunity to do justice to the project parameters within the apprenticeship programs for which trial class had been pre-determined. The class that had already been selected for the project comprised pupils who, with regard to academic achievement, possessed considerably poor prerequisites. The pupils of all previous trial classes were, as a rule, those who had not made it from the elementary school to the sixth class, rather realigned from the 5th, 4 th or even the 3 rd class into the "regime préparatoire".

\section{The implementation of the project \\ Trial class}

Until now, the pilot study has been implemented with 7 to 8 pupils from their respective 7th class, school years (2007-2008, 2008-2009, 2009-2010). During school year 2009/2010, the pilot study was resumed in the following class of the $7 \mathrm{MO}$, i.e., the 8 th class.

The assignment of pupils to the trial class was neither a result of special competencies nor deficits in athletics or language. It was more a matter of pupils with distinctively weak academic achievement. Socio-cultural as well as linguistic prerequisites did not play a role in the selection process. The distribution of nationalities (43\% Luxemburgish, $39 \%$ Portuguese, as well as other nationalities) corresponds to the general circumstances in the 
Luxemburg school system. Many pupils, however, live with especially difficult familial circumstances (live in refugee shelter, boarding school or single-parent home, experience family violence...). Two-thirds of the pupils are boys, which reflects the general situation in which the especially slow learners, an inordinate number of boys, are represented.

After particularly negative experiences with social behavioral problems in the first trial class, a conference was held with the pupils' legal guardians regarding acceptance into the class of the following year. Subsequently, the students selected for the trial class were those whom one could assume would exhibit no extreme behavioral problems and who had parents who appeared to be cooperative.

\section{Content of the subject experience education}

Instead of the usual 3 hours, the physical education teacher has an extra 3 hours of physical education for the trial class. Altogether, the allocation of weekly hours for the trial class would be extended by 3 hours.

The entire physical education class always took place at the Lultzhausen reservoir. For watersports activities, the infrastructure of the public Lultzhasuen Base Nautique were utilized as well as supported by Base Nautique personnel. Aside from this, there is a climbing wall located in Lultzhausen.

The point of the physical education classes for the trial classes is not primarily to orally instruct the pupils in movement techniques and sports. These hours are used for experience-oriented activities such as: kayaking, sailing, climbing, mountain biking, and orienteering. With this in mind, the subject is not termed "sports" rather designated as adventure education.

\section{Linguistic communicative objectives in experience education}

It is common knowledge that in physical education the percentage of language usage is lower than that of other school subjects "because the motor elements take up a large part of the lesson. Despite this, verbal communication takes place at many points" (Nietsch, Vollrath, 2003, p. 150). In order to promote language development within a physical education class, the teacher should consciously seize and utilize potential productive moments as well as the general linguistic communication as with the specific sport activities:

- A great emphasis is placed on linguistic presentation, introduction and acquisition of vocabulary, oral instructions, statements and explanations.

- The physical, athletic and social experiences in sports are explored, reflected upon, eliciting linguistic production from pupils.

- The communication between learners as well as between the learners and teachers is practiced and reflected upon.

- As a result, the pupils' knowledge about the role of movement in life and society is expanded. There are good reasons to assume that through linguistic help, not only linguistic and cognitive competencies are fostered, rather the effective design of physical education activities as well (see Becker, 1990; Barntnitzky, 2006). 
From the pupils' points of view communication in physical education class proceed predominantly receptively. Conscious of this danger, teachers should attempt to plan lessons so that pupils are themselves linguistically active. To which extent lessons must be supported by non-verbal methods, (demonstration, mimic, gesture, etc.) and comprehension enabled or facilitated, must be gauged by qualified teachers and is dependent upon the linguistic skills of their pupils and the respective objectives.

In the first trial class of school year 2007-2008, Luxemburgish was used as the language of communication for the subject of experience education, as is customary in the Luxemburgish school system. Although not all the pupils at this class level interact in Luxemburgish, it is the language of which most pupils have command and which is most suitable for general communication and promotion thereof through physical education.

Due to the classroom constellation of the following year - one pupil spoke only German at the beginning of the year - German prevailed as the language of communication even though German is for many pupils - especially the Portuguese - by no means the language of which they have the best command. Also, for weak pupils with Luxemburgish as their mother tongue, German remains to a large extent a foreign language. The fact is, however, that in this trial class German was used almost exclusively in physical education class. This thereby confirmed the fact that usage of a foreign language in physical education has many advantages:

- Pupils become acquainted with using a foreign language in a real-life situation as a means of communication and as a means of coping with everyday life.

- It is observed that pupils accept the sequence of communication in a different language and are even proud to be able to express themselves in a foreign language. In showing the students quite plainly how to use of the German language as a means of communication to cope with concrete situations in everyday life, their self-assurance, self-confidence, and thereby their identity is strengthened.

- Longer phases of deliberation before linguistic utterances are required (increased self-reflection, fewer emotional, linguistic utterances, limited use of slang, teenage talk).

On the other hand, pupils who do not have such a good command of a language can, in physical education class, more easily compensate for the linguistic hurdles because the linguistic utterances can be further explained through an observable activity or visual support. This results in a sense of achievement in comprehension that strengthens self-efficiency and helps to overcome the distancing of oneself from a foreign language.

Based on positive experiences with the introduction of a foreign language in physical education class, the model has also been carried over into the 8th class into which the trial class, after the 7th class, was transferred. In the 8th class of the Luxemburg school system, however, French is henceforth introduced as the language of instruction along with German. 


\section{Integration of adventure education and language in language class}

One of the basic concepts of the pilot project is the interdisciplinary integration of sports and language(s). For this purpose, the teachers jointly discuss and plan the lesson content and its integration into their lessons.

The starting point of language work is the real experiences of the pupils in the comparatively natural social environment within the subject experience education. With many other subjects, in contrast, the learning process is schooled, institutionally ritualized and thereby out of touch with everyday life. They require previous knowledge or experiences which the pupils have had or made within their familial or social everyday reality. For this reason, many pupils who come from a difficult social environment are often, from the outset, unable to cope; the "culturally influenced" subject material is quite foreign to them. In the pilot project, one's own human corporeality and physical movement become the subject material; one's own experiences are linguistically processed. By these means, school subject matter become meaningful to the pupils as the physical education and language lessons concern the pupil, allowing them to open doors to self-discovery.

In detail, the following linguistic activities, characterized by a product-oriented lesson, are implemented, based on and refer back to athletic experiences.

- A sport specific vocabulary is to be further developed and used in written form.

- For each theme, i.e., each respective sport (for example kayaking), a poster with diverse aspects and facets of the topic is to be created elaborated on by the pupils in oral, then later in written form.

- The real experience by the students is documented by photos which are taken by the pupils of themselves during their athletic activities. These photos are used as stimulus and a basis for the identification, description, and reporting in language lessons.

- The LNW has a recording studio at its disposal (Radio LNW). There, the oral reports and commentaries are recorded and can easily be played back to follow the development of competencies in oral speaking.

- As far as possible, authentic material that corresponds to the sports in physical education class is used (non-fiction books, texts relating to these sports). Thus, for instance, for a standardized language test, a text is selected about a 14 year-old boy who crosses the Atlantic alone in his sailboat. With the selection of such a text, one strives to provide pupils with the chance to identify with a character that is, on the one hand, a protagonist of about the same age, and on the other hand, implements the concept of adventure education in sailing.

This written language test has been implemented at the beginning of each year as a navigational tool in the regulation of language lessons so that pupils could be picked up where they left off. The results have been compared with those of other classes from the elementary and secondary school sector.

In comparison with other classes, in the area of text content comprehension, the pupils from the trial classes performed best. The gravest deficits were in the formal, linguistic 
areas of meta-language, grammatical correctness, and determination of orthography, which was not surprising as these are also competency areas in which, to a high degree, is a basis for school selection as well as pupil orientation into the lowest secondary school sector. Also in the productive speech areas (speaking and writing), however, it was observed through the initiation of a class parliament that the pupils were barely able to formulate thoughts, i.e., neither orally nor in written form.

Within the project framework, it has therefore been decided in language lessons, to privilege the areas in which the pupils have pre-existing competencies which could be built upon and which are fundamental to and useful in both their professional and private lives. Specifically in physical education class, emphasis has been placed on oral communication ${ }^{1}$. The pupils should learn, communicatively, how to behave appropriately and to express themselves understandably for others in everyday communication.

\section{Evaluation of the pilot project}

\section{Adjustments in the project question}

The project acted on the assumption that an integration of physical education class and language lessons influence or can influence the academic and especially the linguistic performance of the pupils.

Although the numbers of test subjects were already too inadequate for an empirical analysis, it was observed that with academically weak pupils - pupils with little willingness to learn and problematic social behavior - developments in purely athletic and linguistic areas and their interdependence cannot be isolated from the entire context. The academic and personal development of the pupils could not be, within the framework of the pilot project, mono-causally traced back to an integrated, modified design of physical education class and language lessons. This cannot even be asserted with the academic performances in physical education and language, the actual subjects of the project. The effects of the modified programs were of a much more general nature.

It has become clear how much of a decisive role key qualifications (social skills, motivation for and interest in school, ability to concentrate...) play in education and learning processes. The learning requirements have been unarguably, decisively influenced by the modified lesson design and once again have had a back-coupling impact on the results in the subjects of physical education sports and language.

\section{The project has sharpened the points of view regarding}

- Those aspects that make the learning processes difficult or hinder weak learners, pupils who are disinterested, resigned or have behavioral problems and

\footnotetext{
1 Particular attention should be given to the fact that from the entire hourly quota for the subject of German, only 1-2 weekly hours for the cooperation of the experience education/language have been used, whereby in the other hours, the students work in their usual program. This should prevent the trial class from becoming a dead end; a switch from the trial class back into the regular class should remain possible.
} 
- the fundamentals, which initially must be set up as requirements if these pupils, with their cognitive, mental, linguistic and psychic problems, really are to be offered a new chance through a "new" school.

For this reason, the project question shifted and turned out to be much more general:

Do the lesson modifications carried out in the project offer the concerned pupils a chance for a new start in their hitherto little successful academic track? What role do sports play? What role does a conception of language lessons based on sports play? What effects does lesson design, based on the pilot project, have on the pupils?

\section{Promotion of key qualifications}

An abundance of data has been collected and analyzed in order to describe the developments of the students in the trial class. ${ }^{2}$ Important clues to the development of key qualifications have been provided by the evaluation sheet filled out together by the teachers in the teachers' conferences, which distinguished between the following subjects: learning habits, working habits, social behavior, and subject competence.

The following summary of positive developments in the areas of social competence, motivation and concentration were observed, even if naturally, gradual individual differences were recorded:

Social competencies:

- The trial class develops strong group dynamic and accordingly, ability to work in a team

- Especially large progress is made in pair work.

- The pupils try to solve problems independently; they work under increasingly less direction from the teacher, develop more autonomy so that more self-initiated learning takes place.

- The pupils take over increasingly more responsibility for the entire group, i.e., by individuals who are appointed as coach or referee or a team.

- With improvement of their self-confidence follows increased identification.

Motivation:

- Obviously the pupils enjoy coming to school. They feel comfortable in the class and are interested in performing well, developing their strengths, and reducing their weaknesses.

- Their self-confidence is strengthened; they are proud of their accomplishments.

Concentration:

- The pupils identify with the academic activities. Therefore they succeed in mobilizing their abilities of concentration in the learning situation.

2 To this end, alongside the official documents,(traditional marks, promotion decisions), products from the pupils (poster, radio reports...) are the findings from the field reports of the teachers, and educators of the trial class, opinions of the pupils and parents. 
- The pupils are characterized by order, discipline, high attentiveness, i.e., always having the necessities with them.

Despite understandably scientifically theoretical doubts in terms of the determination of learning effects in the social, emotional and motivational spheres, one can observe that the positive developments correspond to the lesson design modification measures within the project framework.

Adventure education provides an important role in the development and promotion of social competencies: sports foster cooperation, indispensable under certain circumstances like climbing or orienting. Through the development and promotion of teamwork in physical education the ability to work in a team is developed, which has positive implications for all school achievement.

Interesting experience- and adventure-oriented activities that are tested in physical education class and then subsequently processed in language lessons promote not only interest in these subjects, rather improve the complete attitude of learners toward school, as well. The evaluation of a questionnaire handed to the parents shows that a significant yield of the project is the existence of an improved and respectively renewed interest in school, which also positively affected the development of core competencies in all subjects. The resulting motivation also favorably impacted concentration as an essential requirement for the initiation and development of learning processes.

The implementation of a power of concentration test (d2-KLT-Test from Brickenkamp) at the beginning of each school year, resulted in a surprisingly high level of ability to concentrate, which these pupils, due to lack of interest, obviously could not or did not want to mobilize. The pilot project showed that a high relevant significance is attached to the development and promotion of key qualifications in work with weak pupils and pupils with disciplinary issues. One cannot assume that with these pupils, the key qualifications exist to the desired or required extent for the development of professional expertise. Because for many pupils, mainly those with little academic success and for those many cases where no seamless transition from school into the job world is possible, one must continue to work on or rework the educational and instructional requirements for their integration into the professional world. Until now, one has begun anew mostly with the same content and methods anyway, with pupils who have both mentally and emotionally shut out traditional schooling. Through the accentuation of key qualifications, one can create an interdisciplinary-integrated, or rather a transversal framework that communicates to these pupils - with respect to lifelong learning - better (multi-) functionality or more professional perspective, and ultimately, life skills.

\section{Tasks of physical education}

With a real comeback, sports can play an important role because pupils do not clearly link the subject with their conception of the institution of school. This may count even more for experience-oriented, unconventional sports than for the traditional, within the environment and media prevalent sports. 
Physical education teachers must, however, become aware of the potential of their subject and be willing to cooperate with teachers of other subjects and further accept that they, to a certain extent, provide support for other subjects and teachers. In addition to the traditional objectives of physical education such as the promotion of motor abilities and skills, of physical well-being and health, the physical education class - together with other subjects - should be primarily aimed at the development and promotion of key qualifications. Additionally, they must learn and implement communicative strategies for lessons with pupils in order to contribute to the development of linguistic competencies that actually do not immediately belong to the objectives of physical education. ${ }^{3}$

\section{Tasks of language lessons}

In that, the physical education teachers' objectives overlap with those of the language lessons, which for their part is likewise obligated to oral primacy: "The main emphasis shall be placed on the spoken and received language" (Barntnitzky, 2006, p. 24), "because the children here have developed their most advanced linguistic skills." This means the language teacher is again prepared to subordinate the development of linguistic skills especially in the area of writing as spoken, which traditionally characterizes language lessons. The rehabilitation of grave deficits in other linguistic skills can follow with successful integration into professional life within the framework of lifelong learning.

Language lessons do the preliminary work of other subjects if the language is developed and promoted as a medium for any kind of lesson. Other subjects provide, for their part, attractive, meaningful and motivating content for language lessons. In this way, athletic activities with their special content and methods, in the frame of experience education undoubtedly has a decisive share in the instruction of key qualifications and communication skills. Then again, the improved key qualifications provide an optimal basis for the promotion of core competencies in language lessons and other school subjects.

\section{References}

Barntnitzky, H. (2006). Sprachunterricht heute. Sprachdidaktik - Unterrichtsbeispiele Planungsmodelle. Berlin: Cornelsen Verlag Scriptor,.

Becker, W. (1990). Einfluss von Lernerfahrungen auf die Veränderung der Informationsverarbeit ungsfähigkeit bei Kindern und Jugendlichen durch unterschiedliche Modalitätspräreferenzen. Stuttgart / New York / Egelsbach: Hänsel-Hohenhausen.

\footnotetext{
3 Beyond the problem of the connection between physical education and social learning, the problem of scientific evaluation exists. A central difficulty in the area of social learning, as well as in experience education, lies in the fundamental uncertainty about the determination of learning effects. The isolation of parameters or indicators which could help determine and realize social learning objectives and the appraisal of stringent causalities within the social learning processes, have not, as of yet, been reached
} 
Becker, W. (2009). Perspektiven-vielfalt beim Lernen lernen im europäischen Kontext für Multikultur, Mehrsprachigkeit, und Migrations-problematik. Bad Tönning: Der Andere Verlag.

Berg, C., Weis, C. (2007). Reajustement de l'Enseignement des Langues. Plan d'action 2007-2009. Luxembourg: Editions du CESIJE.

Bergermann, S. (2003). Perspektiven für die Einbindung des Faches Sport in bilinguale Zweige an weiterführenden Schulen. (Unpublished document). Ruhr Universität, Fakultät für Sportwissenschaft, Bochum.

Bös, K., Brochmann, C., Eschette, H., Lämmle, L., Langers, M., Oberberger, J., Opper, E., Romahn, N., Schorn, A., Wagener, Y., Wagner, M., Worth, A. (2006). Gesundheit, motorische Leistungsfähigkeit und körperlich-sportliche Aktivität von Kindern und Jugendlichen in Luxemburg. Untersuchung für die Altersgruppen 9, 14, und 18 Jahre. Kurzbericht zum Forschungsprojekt. Karlsruhe und Luxemburg: Universität Karlsruhe (THT), MENFP, MS \& DMS.

Brickenkamp, R. (2002). Test d2 Aufmerksamkeits-Belastungstest. Göttingen: Hogrefe.

Nietsch, P., Vollrath, R. (2003). Physical Education. Sprachlernpotential im bilingualen Sportunterricht. In: E. Otten, , M. Wildhage. Praxis des bilingualen Sportunterricht. Berlin: Cornelsen Scriptor, p. 147-169.

Segets, M. (2008). Soziales Lernen und Erlebnissport in der Schule. Sportpraxis, (Mar 2008), p. 6ff. Wilsdorf, D. (1991). Schlüsselqualifikationen. Die Entwicklung selbständigen Lernens und Handelns in der industriell gewerblichen Berufsausbildung. München: Lexika Verlag.

\title{
Fizinis ugdymas ir kalbos plètojimas
}

\author{
Werner Becker ${ }^{1}$, Romain Sahr ${ }^{2}$
}

1 Liuksemburgo universitetas, Kalbos ir literatūros, humanitarinių mokslų, menų ir ugdymo fakultetas, Route de Diekirch, L-7220 Walferdange, el. paštas werner.becker@uni.lu

2 Liuksemburgo universitetas, Kalbos ir literatūros, humanitarinių mokslų, menų ir ugdymo fakultetas, Route de Diekirch, L-7220 Walferdange, el. paštas romain.sahr@uni.lu

\section{Santrauka}

Straipsnyje analizuojami Kalbos veiksmų plano „Veiksmas 53“ bandomojo tyrimo rezultatai, kurio metu analizuotas ryšys tarp paauglių fizinio ugdymo ir kalbų mokymosi. Remiamasi prielaida, kad plètojant paauglių fizinį ugdymą bei intensyvinant jų sportinę veiklą yra skatinami bendrieji paauglių pažintiniai gebejjimai, jų lavinimas. Pagrindinis projekto tikslas - nustatyti paauglių fizinị išsivystymą ir kalbų mokymosi lygị, sutelkiant dèmesị ị jų kalbinès kompetencijos plètrą jiems nuolat dalyvaujant sporto veikloje. Straipsnyje pateikiami ir analizuojami 
aukštesniųjų klasių (15-18 m.) mokinių ( $\mathrm{N}=126)$ tyrimo duomenys, taikant standartizuotus aprašus, siekiant įvertinti dalyvių kalbos ịgūdžius. Fizinio pasirengimo lygmeniui nustatyti su 7-8 mokiniais buvo atliekamas konkrečios sporto šakos bandymas. Tyrimo metu buvo siekta nustatyti tiriamųjų asmeninio tobulejjimo, pažinimo raidą, mokyklos veiklos mastą, parodant sąsajas tarp sporto ir kalbų mokymosi bei jų tarpusavio poveikị. Remiantis bandomojo tyrimo išvadomis, būtina plèsti tyrimo apimtis, perkeliant bandomojo tyrimo modelị $\mathfrak{i}$ kitų mokyklu kontekstą, nagrinėjant tolesnę scholastikos ir karjeros plètrą, tęstinị sistemų dalyvių ir vertinimo metodų kūrimą, atsižvelgiant ị tradicines švietimo priemones, egzaminus ir kt. Būtina atsižvelgti ì ypatingą kūno kultūros ir kalbų mokymosi tarpusavio ryši ir priklausomybę.

Bandomasis projektas parode, kad integruotas mokymo turinys, ịvairios mokymosi sąlygos, tinkamas mikroklimatas mokykloje gali padèti sukurti ir plètoti visiems, tiek atskiriems dalyko mokytojams, tiek kiekvienam vaikui, priimtinas sritis.

Raktiniai žodžiai: Fizinis ugdymas, kalbinès kompetencijos plètra.

Itteikta / Received 2012-03-01 Priimta / Accepted 2014-03-01 